\title{
The Effect of Marketing Challenges on the Performance of Small and Medium Scale Enterprises: (A Case of Loka Abaya Woreda, Sidama Zone, SNNPRS, Ethiopia)
}

\author{
Mathewos Yure Dangisso \\ Lecturer of Furra Development studies \& Education
}

\begin{abstract}
Small and medium enterprises played a great role for economic development and employment creation. The purpose of this study is to assess the effect of marketing challenges on the performance of SMEs a case of Loka Abaya woreda. Primary data was collected through structured questionnaires from 220 respondents. SMEs Operators and managers' were selected by stratified random sampling techniques. Interviews were also conducted with stake holders of woreda government bodies and managers. Qualitative and quantitative research approaches were employed. In this study Descriptive research were used to analyze the research data. Descriptive statistics such as percentage, mean, and standard deviation is used, while inferential statistics were used such as Pearson correlation, and multiple regressions analysis.It was found out that $\left(\mathrm{R}^{2}=0.805\right)$ implied that independent factors: production \& selling place, marketing factor, promotion, distribution channels and pricing, predicted $(80.5 \%)$. The dependent variable performance of SMEs predicted by the rest $19.5 \%$ accounted by other factors. The findings of the study also revealed that marketing factors has a higher effect on the performance of SMEs followed by pricing challenges. Therefore, SMEs in the woreda, Sidama zone responsible bodies, Loka Abaya woreda responsible bodies and the government can take appropriate measures to solve the problems related to independent factors in this study to improve SMEs performance.
\end{abstract}

Keywords: SMEs, marketing challenges, SME performance, Loka Abaya woreda.

DOI: $10.7176 / \mathrm{JMCR} / 55-05$

Publication date: April $30^{\text {th }} 2019$

\section{INTRODUCTION}

The micro and small business sector is recognized as an integral component of economic development and a crucial element in the effort to lift countries out of poverty (Wolfenson, 2007). Different economists and scholars state a number of multi-dimensional reasons for the presence of developing countries level. Lack of sufficient capital and investment is expected to be among the major tangible reasons for underdeveloped economic status of these countries (Todaro, 2003).

The dynamic role of micro and small enterprises (MSEs) in developing countries as engines through which the growth objectives of developing countries can be achieved has long been recognized. It is estimated that SMEs employ $22 \%$ of the adult population in developing countries (Fisseha, 2006). Similarly, Lara and Simeon (2009) found out that SMEs sector generates substantial employment and economic output in many countries.

Perceiving the SMEs themselves as a reflection of poverty and backwardness, waiting government jobs rather than innovation, poor saving culture, limited access to sufficient finance and economic dependency are some of the perception related challenges that needed the attention of the government (MOTI, 2011).

The researcher investigated the existing marketing phenomena empirically there by an attempt would be made to identify the effect of marketing challenges on the performance of SMEs, by taking a case study on operators of Loka Abaya woreda. In addition, this study focused on real effects of marketing challenges on the performance of SMEs in Loka Abaya woreda.

\subsection{Statement of the Problem}

The marketing of Small and medium sized enterprises (SMEs) has long been regarded as crucial for the achievement of broader marketing objectives, including poverty alleviation by generating revenue, and employment creation, economic development, and the promotion of more democratic and pluralist societies.

This can be mainly achieved through employment creation, revenue generation, and economic stimulation for which government of Ethiopia allocated 10 billion birr for youth project and for employment creation (FeMSEDA, 2017/18). For instance, the current 2018 years plan of FeMSEDA aimed to create job opportunity for 2 million youths throughout the country (FeMSEDA, 2018).

Bringing the existing and emerging SMEs from the attitude in which they have been operating in emerging economies, particularly in our country, requires lots of trainings, awareness raising and practical convincing supports. According to the BDS market assessment research undertaken by Digital Opportunity Trust, on average exceeding $80 \%$ of SMEs operating in four regional cities (Addis Ababa, Hawasa, Bahirdar and Mekelle) showed that they are enterprises operated by the owner only and the owners started the business at the point 
where their livelihood was challenged (DOTE, 2014). Generally these SMEs support the day to day existence of the family leaving no saving for expansion and further growth.

Few researches have been conducted on marketing constraints and its effect on performance of SMEs. These studies mainly focused on effectively addressed marketing challenges of SMEs, and its effects on SMEs performance. In order to fill this research gap, this research is conducted assessing marketing challenges on the performance of SMEs in Loka Abaya woreda. The following problems of SMEs are identified in the Loka Abaya woreda:

- $\quad$ Lack of suitable production \& selling places

- Problems of marketing factors (marketing skill, customer relations management, demand forecasting \& soon)

- Promotion challenges

- Distribution channels problems

- $\quad$ Pricing challenges woreda.

Therefore, the purpose of this study is to assess above listed marketing challenges of SMEs in Loka Abaya

\subsection{Objectives of the Study}

The general objective of this study is to assess the effects of marketing challenges on the performance of small \& medium scale enterprises in Loka Abaya woreda.

\section{The Specific objectives of this study}

1. To examine the effects of production and selling places on the performance of SMEs.

2. To examine the effects of marketing factors (demand forecasting, marketing skill, and customer handling practices) on the SMEs performance.

3. To identify the effects of promotion on SMEs performance

4. To examine the effects of distribution channels on SMEs performance

5. To analyze the effects of pricing challenges on SMEs performance

\subsection{Research Hypothesis}

This study aims at to fill the research gap bringing the desired solution to the effects of marketing challenges on the performance of SMEs in the study area. Therefore, to achieve the objective of this study the following hypothesis was proposed:

Ho1: Production and selling place challenges has no significant effects on SMEs performance

Ha1: Production and selling place challenges has significant effects on SMEs performance

Ho2: Marketing challenges has no significant effect on SMEs performance

Ha2: Marketing challenges has significant effect on SMEs performance

Ho3: Promotion challenge has no significant effect on SMEs performance.

Ha3: Promotion challenge has significant effect on SMEs performance.

Ho4: Distribution channels have no significant effect on marketing performance of SMEs.

Ha4: Distribution channels have significant effect on marketing performance of SMEs.

Ho5: Pricing challenges has no significant effect on SMEs performance.

Ha5: Pricing challenges has significant effect on SMEs performance.

\section{Challenges of SMEs}

Efforts to promote the development of SMEs often involve helping entrepreneurs solve problems that constrain their growth. To do this effectively, it is helpful to know the most serious problems (the "binding constraint") that small enterprises face. Liedholm and Mead (1999) conducted a research in five African countries and found out that three categories of problems were predominant and these include: access to capital, problems of markets, and access to raw materials and intermediate inputs. In their survey, they also added that the problems seen were generally similar both in male-owned and female-owned businesses.

Ishengoma and kappel (2008) proved that investment obstacles, limited access to market and productive resources and high tax hinder the growth potential and performance of SMEs in Uganda. Most Ethiopian SMEs face critical constraints both at the operation and start up level. Some of these constraints include lack of access to finance, lack of access to premise, lack of infrastructure, lack of training in entrepreneurial and management skills, lack of information on business opportunities, social and cultural facts, in particular deficient entrepreneurial culture and excessive corruption (HLCLEP, 2006). According to (Hailay.G,2003), the main problems of small businesses in Ethiopia are lack of adequate finance, lack of credit, marketing problems and problems related to production which includes techniques of production mostly outdated and lack of qualified raw materials at reasonable price. The above evidences are more or less consistent with Stevenson \& St-Onge (2005) study which identified constraints which can affect market performance of SMEs in developing countries. 
The challenges are listed as follows:

- Unfavorable legal and regulatory environments and, in some cases, discriminatory regulatory practices;

- Lack of access to markets, finance, business information;

- Lack of business premises (at affordable rent);

- Low ability to acquire skills and managerial expertise;

- Low access to appropriate technology.

\subsection{Marketing factors challenges}

A marketing manual prepared by FeMSEDA identifies three market opportunities for SMEs. These markets are classified based on the geographic outreach of SMEs as local market, regional market and national/international market. The manual suggests that SMEs should target their immediate local markets where the rural-urban linkages could be strengthened through identifying and meeting the demand of the market. Then SMEs could broaden their scope and get more competent to serve the regional markets and they should target supplying national and export markets (FeMSEDA, 2014)

According to EDRI, despite the efforts exerted to create market linkages there are a number of setbacks.

The challenges include that, many of the SMEs are not benefiting from the support schemes, the support scheme made by the government created dependency and unnecessary Expectation on SMEs, lack personal initiatives to search for market. Due to failures to properly use the market linkage opportunities, SMEs have failed to serve their debts timely; their products could not be sold or are sold at loss. Rent seeking behaviors observed on both the SMEs and the bureau officials have exacerbated the market linkage problems. Most of the government induced linkages which target holidays and festivities created only temporary jobs. Moreover lack of detailed support packages, poor implementation of packages coupled with limited market information are hampering the development of SMEs to access market for their products (EDRI, 2014).

\subsection{Working and selling place constraints}

Access to working and sales premises are also the other challenges to SMEs operating in the country. To this end, a national strategy was designed to construct appropriate working shades indifferent parts of the country.

As a result considerable number of manufacturing and service rendering premises have been built and offered to both SMEs that are working in the manufacturing and service sectors (FeMSDA, 2015). EDRI in its survey identified that constraints in the area of working and sales spaces include, limited accessibility of the sheds, distant location of the constructed sheds from large and medium enterprises, non-suitability of the quality and size of the constructed sheds and gradual return ability of the sheds without any replacement of another space are among the challenges that the SMEs are facing in the area (EDRI, 2014).

\subsection{Distribution channels problems}

In the field of marketing, channels of distribution indicate routes or pathways through which goods and services flow, or move from producer to consumers. We can define formally the distribution channel as the set of interdependent marketing institutions participating through which a commodity, in the marketing activities involved in the movement or the flow of goods or services from the primary producer to the ultimate consumer.( N.G.Nair \& Latha Nair, 2011).

A channel of distribution or marketing channel is the structure of intra company organization units and extra company agents and dealers, wholesalers and a retailer through which commodity, product or services is marketed(Americans marketing association, 2010).

Distribution channel is a set of independent organization involved in the process of making a product or services available for use or consumption by the customer or industrial user (Kotler, 2004). Most SMEs distribution channels in Ethiopia have different challenges (Gebrehiwot, A. and Wolday, A., 2004). According to Federal ministry of trade and industry most of SMEs faced different distribution channels problems, channels selection and motivation (MoTI, 2011).

It is a business structure of interdependent organizations from the point of product origin to the consumer with the purpose of moving products to their final consumption .destination (Kotler and Armstong, 2003).

The analysis of marketing channels is intended to provide a systematic knowledge of the flow of goods and services from their origin (producer) to their final destination (consumer).

This knowledge is acquired by studying the participants in the process, i.e. those who perform physical marketing functions in order to obtain economic benefits (Getachew, 2002). This channel may be short or long depending on the kind and quality of the product marketed, available marketing services, and prevailing social and Physical environment (Islam et al., 2001). Intermediaries normally achieve superior efficiency in making goods widely 


\subsection{Promotion challenges}

Today there is a new view of communications as an interactive dialogue between the company and its customers that takes place during the pre selling, selling, consuming, and post consuming stages. Successful companies are asking not only "How can we reach our customers" but, in a break from the past, are also asking "How can our customers reach us" (Kotler, 2005). Increasingly, it is the newer technologies, such as the Internet, that have encouraged more firms to move from mass communication to more targeted communication and one-to-one dialogue with customers and other stakeholders.

There are eight steps to follow in developing an effective marketing communications program:

* Identify the target audience,

* Determine the communication objectives,

* Design the message,

* Select the communication channels,

* Establish the total communications budget,

* decide on the communications mix,

* Measure the communications' results, and

4 Manage the integrated marketing communication process.

Source: Kotler millennium edition (Kotler 2002).

In different businesses marketing promotion tools like advertisement, personal selling, e-commerce, epromotion, publicity, exhibitions, bazaars, trade fairs and telecom facilities in different area confronted as huge challenges to communicate with their customers (MoTI, 2011).

\subsection{Conceptual Framework of the Study}

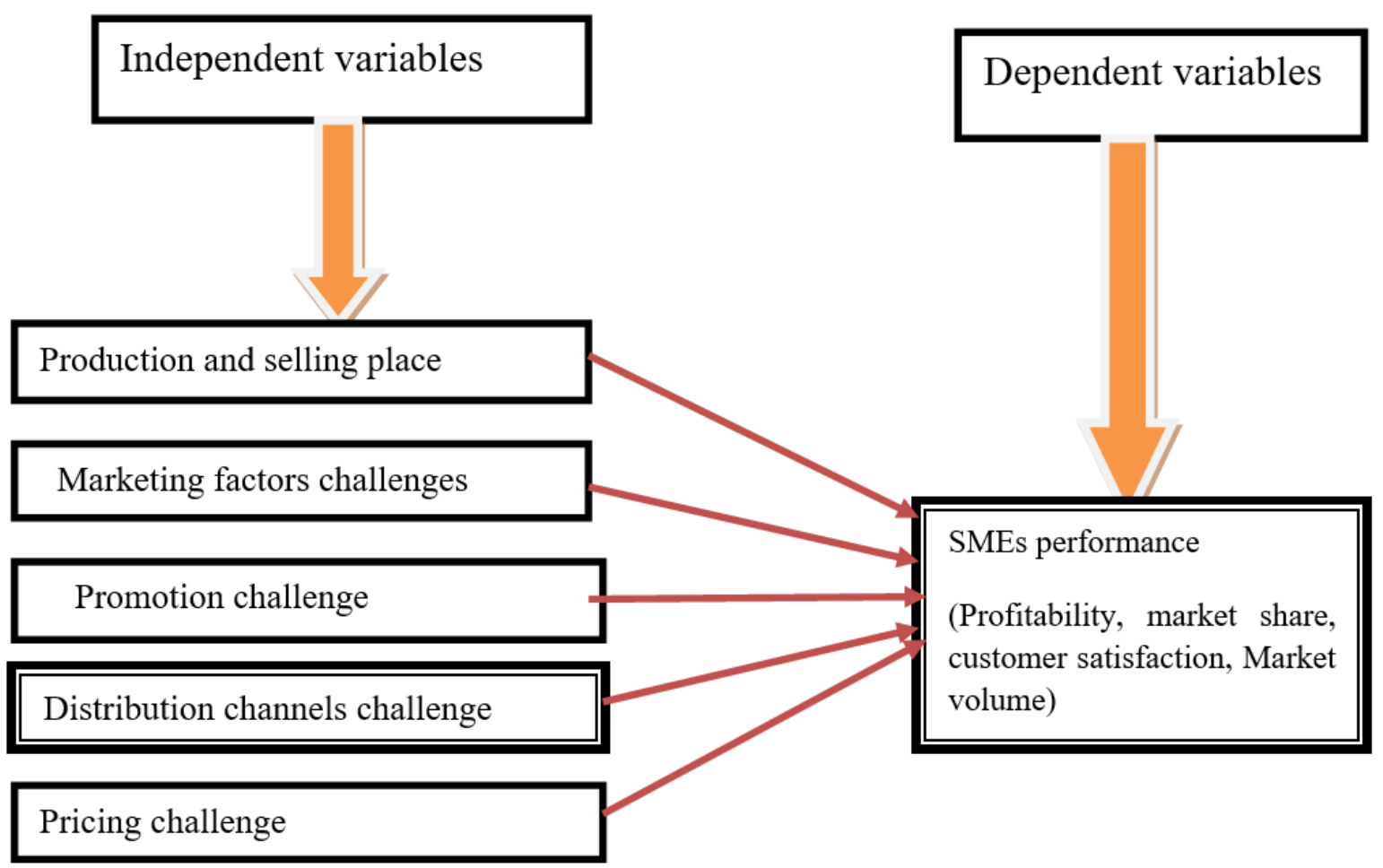

Source: Adopted from Matra et.al 2010 and, modified by the researcher, (2018).

\section{RESEARCH METHODOLOGY}

\subsection{Research design}

The types of research employed under this study were descriptive and explanatory research. The major purpose of descriptive research is description of the state of affairs as it exists at present. Then this study described and critically assessed the effects of marketing challenges on performance of SMEs in Loka Abaya woreda.

The second step was the study employed explanatory research to evaluate the casual relationship between independent variables and dependent variables with the aim of estimating the integrated influence of the effects of marketing challenges on the performance of SMEs.

The study also employed both primary and secondary data from both primary and secondary data sources. Currently there are 147 SMEs in Loka Abaya according to woreda urban development and housing office (2018) 
and 489 operators 220 sample operators and managers selected. Secondary data was collected from urban development and housing office of the Woreda. Primary data also collected through structured questionnaire and interview conducted with SMEs managers' government officials. The main sources of secondary data included reports of organizations, business books, and journal articles, different SMEs related manuals, internet, and reports of other stakeholders' institutions.

\subsection{Types and source of data \\ Primary data}

Primary data is actually first hand data or the information collected by researchers via direct observations. Normally, primary data is collected through observation methods, surveys, interviews, and experiments instead of other sources which are available for public access (Kotler, 2012). Primary data used for this research is collected by using structured questionnaires and interviews for small and medium enterprises owners (operators), and managers of SMEs were selected by using simple random sampling method.

\section{Secondary data}

Secondary data is very important to get information related with the research topic. The main sources of secondary data include reports of organizations (annual reports of urban development and housing office, reports from TVET, Trade and industry, SMEs bureau (agency) business books, and journal articles, different SMEs related manuals, internet and reports of other stakeholder institutions.

\subsection{Target population}

Hair, Wolfinbarger, Ortinau and Bush (2008) defined a targeted population as consisting of the complete group of elements (people or objects) that are identified for investigation based on the objectives of the research. Target Population of SMEs in woreda, according to the reports of Small and medium Enterprises and urban development and housing office (2017) the total population of the SMEs in the study area is 147 and its operators are 489 among those, 23 are manufacturing, 21 are urban agriculture (dairy farming, fattening and poultry farming), 21 are construction 34 are trade and 48 are service sectors, the owners of small \& medium scale enterprises are 489 from these 307 are male and 182 are females. From each SMEs identified above Sample sizes are taken for the intended study.

\subsection{Sample size and sampling techniques}

The study employed stratified random sampling presented by Yemane (1967): precision 5\% to determine the sample size of the study Yemane (1967) sample size formula used in this study by using stratified random sampling technique.

$$
\begin{aligned}
& \mathbf{n}=\mathbf{N} /\left(\mathbf{1}+\mathbf{N}\left(\mathbf{e}^{2}\right)\right) . \\
& \mathbf{n}=\text { sample size } \\
& \mathbf{N}=\text { Total population of SMEs operators }=489 \\
& \mathbf{e}=\operatorname{error}(0.05) \\
& \mathrm{N}=489 \\
& \mathrm{n}=489 /\left(1+489(0.05)^{2}\right) \rightarrow \mathrm{n}=\underline{220}
\end{aligned}
$$

\begin{tabular}{|c|c|c|c|c|c|c|c|}
\hline \multirow[t]{2}{*}{$\mathrm{S} / \mathrm{N}$} & \multirow[t]{2}{*}{ Types of SMEs } & \multirow{2}{*}{$\begin{array}{l}\text { Total } \\
\text { populations of } \\
\text { SMEs }\end{array}$} & \multicolumn{3}{|c|}{$\begin{array}{l}\text { Owners(operators)of } \\
\text { SMEs }\end{array}$} & \multirow{2}{*}{$\begin{array}{l}\text { Sampling technique for } \\
\text { SMEs operators } \\
\mathbf{n i}=\mathbf{n} . \mathbf{N i} / \mathbf{N}\end{array}$} & \multirow{2}{*}{$\begin{array}{l}\text { Sample size of } \\
\text { SMEs } \\
\text { operators }\end{array}$} \\
\hline & & & Male & Female & Total & & \\
\hline 1 & Construction & 21 & 49 & 35 & 84 & $220 \times 84 / 489=38$ & 38 \\
\hline 2 & Manufacturing & 23 & 51 & 23 & 74 & $220 \times 74 / 489=33$ & 33 \\
\hline 3 & Service & 48 & 77 & 45 & 122 & $220 \times 122 / 489=55$ & 55 \\
\hline 4 & Trade & 43 & 81 & 43 & 125 & $220 \times 125 / 489=56$ & 56 \\
\hline 5 & $\begin{array}{l}\text { Urban } \\
\text { agriculture }\end{array}$ & 21 & 49 & 36 & 85 & $220 \times 85 / 489=39$ & 38 \\
\hline & Total & 147 & 307 & 182 & 489 & 220 & $\underline{220}$ \\
\hline
\end{tabular}

Accordingly $n=220$

220 questionnaires can be distributed to SMEs operators by using simple random sampling techniques: construction, manufacturing, service, trade, urban agriculture proportionately by using the formula $\mathbf{n i}=\mathbf{n . N i} / \mathbf{N}$, where $\mathrm{ni}=$ sample of strata, $\mathrm{Ni}=$ population of strata, $\mathrm{n}=$ total sample size.

Table 3.1 sampling design and procedure of research

Source :( own Survey, 2018)

\subsection{Data collection methods}

In this research both qualitative and quantitative data were collected from both primary and secondary data sources. Primary data was collected from different micro and small enterprise owners, managers and workers in 
the woreda by using structured questionnaires in the form of Likert scale which ranges from 1-5 (1 strongly disagree and 5 strongly agree), and semi-structured interview. The secondary data were collected from small and medium enterprise work process, urban development and housing office, Small and medium Enterprise Agency, Technical \& Vocational Educational Training (TVET) Center, office of urban development \& housing and also Trade and industry, collected through annual reports. Representatives of different enterprises and concerned stake holders are contacted through interview.

\subsection{Methods of Data analysis}

The data collected were analyzed qualitatively and quantitatively in order to analyze the effects of marketing challenges on the performance of SMEs.

\subsubsection{Descriptive Analysis}

In this section, the study described and analyzed existing phenomena of marketing challenge variables and SMEs performance of the woreda. The descriptive statistics tools such as minimum, maximum, mean, standard deviation, and percentage were used to describe and to test the characteristics of each variable.

\subsubsection{Econometric Model}

Multiple linear regressions (MLR) are statistical techniques that are used in several explanatory variables to predict the outcome of a response variable. Its goal is to model the relationship between the explanatory and response variables. Model equation: The model expresses the value of a dependent variable as a linear function of one or more independent variables and an error term:

$\mathrm{Y}=\alpha+\beta 1 \times 1+\beta 2 \times 2+\beta 3 \times 3+\beta 4 \times 4 \ldots .+\beta n \times n+\varepsilon$

Where, $\mathrm{Y}=$ is dependent variable which indicate SMEs performance.

$\alpha=$ is constant

$\varepsilon=$ is error term

$\beta 1, \beta 2, \beta 3, \beta 4 \ldots \ldots \beta n=$ are coefficient of independent variables

$\mathrm{X} 1=$ Production and Selling place challenge

$\mathrm{X} 2=$ Market factors challenges

$\mathrm{X} 3=$ Promotion challenge

$\mathrm{X} 4=$ Distribution challenge

$\mathrm{X} 5=$ Pricing challenge

Therefore, $\mathrm{X} 1, \mathrm{X} 2, \mathrm{X} 3, \mathrm{X} 4, \mathrm{X} 5, \mathrm{X} 5, \ldots \ldots \ldots \mathrm{Xn}=$ are independent variables

\section{FINDINGS AND DISCUSSIONS}

This study conducted two hundred twenty (220) questionnaires were distributed across the five sectors(construction, manufacturing, service, trade and urban agriculture) in Loka Abaya Woreda SMEs, all questionnaires (220) were completed and retrieved successfully, this was done by enumerators, it represented $100 \%$ return rate. Out of the 220 questionnaire: for construction 38, manufacturing 33, services 55, trade 56, and urban agriculture 38. According to Mugenda (2003) a response rate of $50 \%$ is adequate for analysis and reporting; a rate of $60 \%$ is good and a response rate of $70 \%$ and over is excellent; therefore, this response rate was over adequate for analysis and reporting.

\subsection{Analysis of correlations}

The correlation between marketing challenges (production \& selling place, marketing factors, promotion, distribution, pricing, government support and bureaucratic rule, \& infrastructure) and performance of SMEs

\begin{tabular}{|c|c|c|c|}
\hline S/N & Independent variables & \multicolumn{2}{|c|}{$\mathbf{N = 2 2 0}$} \\
\cline { 3 - 4 } & & $\begin{array}{c}\text { Pearson } \\
\text { Correlation }\end{array}$ & Sig. (2-tailed) \\
\hline 1 & & & \\
\hline 2 & Production and selling place & $.519^{* *}$ & .000 \\
\hline 3 & Marketing factors & $.840^{* *}$ & .000 \\
\hline 4 & Promotion channels & $.798^{* *}$ & .000 \\
\hline 5 & Pricing & $.649^{* *}$ & .000 \\
\hline
\end{tabular}

**. Correlation is significant at the 0.01 level (2-tailed) Sources: (Own survey data, 2018)

As shown in the above table to investigate the relationship between the independent variables i.e. 
production and selling place challenge, marketing challenge, promotion challenges, distribution channels challenge, pricing challenges, with the dependent variable i.e. SMEs performance was studied using Pearson product moment correlation coefficient.

According to the results of correlation analysis in the table 4.12 above some of the independent variables were strongly correlated with the dependent variable i.e. SMEs performance at 95 percent confidence level $(\mathrm{P}<0.05)$. The highest correlation is signified by marketing factors challenges $(\mathrm{r}=.840)$, followed by promotion challenges $(\mathrm{r}=.798)$, pricing $(\mathrm{r}=.761)$, distribution $(\mathrm{r}=.649)$ and lastly production and selling place challenge $(\mathrm{r}=.519)$.

Table above also showed that the higher correlation variable marketing factors challenges affecting performance of woreda small and medium enterprises, its coefficient is 0.840 highest score, the next highest correlation coefficient 0.798 promotional challenge and SMEs performance promotion and SMEs performance have strong relationship, promotional factors challenge influences performance of SMEs. Pricing also has positive coefficient 0.761 , it implied that between pricing and SMEs performance there was substantial positive relationships. These influences pricing strategies of SMEs and SMEs profitability. Distribution channels challenge also have substantial correlation coefficient 0.649 with small and medium enterprises. This implies when the distribution channels challenges solved properly SMEs market performance will be increased by 0.649 , production and selling place challenges on the other hand have positive and medium correlation coefficient 0.519; all variables have positive correlation coefficient that shows all variables have positive relationships with small and medium enterprises performance.

\subsection{Multiple Regression Analysis}

Table 4.2: Model summary

\begin{tabular}{|c|c|c|c|c|c|c|}
\hline \multirow[t]{2}{*}{ Model } & \multirow[t]{2}{*}{$\mathrm{R}$} & \multirow[t]{2}{*}{ R Square } & \multirow{2}{*}{$\begin{array}{l}\text { Adjusted } \\
\text { Square }\end{array}$} & \multirow{2}{*}{$\begin{array}{l}\text { Std. Error of } \\
\text { the Estimate }\end{array}$} & & \multirow[t]{2}{*}{ Durbin- Watson } \\
\hline & & & & & Sig. F Change & \\
\hline 1 & $.897^{\mathrm{a}}$ & .805 & .801 & .23620 & .000 & 2.002 \\
\hline
\end{tabular}

Source: (own survey, 2018)a. Predictors: (Constant), PSP, MFC,PMC, DRC, PRC, GSLP, IFRC, GMC

b. Dependent Variable: MP(SMEs performance)

$\mathrm{R}$ value (.897) shows that, the correlation between the observed value of performance and the optimal linear combination of the independent variables (working \& selling place, marketing factors, promotion, distribution channels, pricing).

The value of adjusted $\mathrm{R}$ square i.e. 0.805 gives some idea of how well the model generalizes and ideally one would like its value to be the same, or very close to, the value of R square. In present study, the difference between the values of $\mathrm{R}$ square and adjusted $\mathrm{R}$ square is $0.805-0.801=0.004$ (about $0.4 \%$ ). This linkage means that if the model was derived from the population rather than from the sample, it would account for approximately $0.4 \%$ less variance.

The standard error of the estimate is a measure of the variability of the multiple correlations. Therefore, as shown in the model summary for the regression analysis table above, the std. error of the estimate of this model is .23620. This implies that the variability of the multiple correlations is as much as this numeral. Positive \& significance of all values showed that model summary is also significant and therefore gives logical support to the present study model. The model is statically significant or the p-value for the model is less than (0.01).This indicates that model is fit to explain all independent variables production \& selling place, marketing factor, promotion, distribution, pricing, affects the dependent variable (SMEs performance).

Table 4. 2: Estimated Unstandardized and Standardized Regression Coefficient

\begin{tabular}{|c|c|c|c|c|c|c|c|}
\hline & Model & \multicolumn{2}{|c|}{$\begin{array}{l}\text { Unstandardized } \\
\text { Coefficients }\end{array}$} & \multirow{2}{*}{$\begin{array}{c}\begin{array}{l}\text { Standardized } \\
\text { Coefficients }\end{array} \\
\text { Beta } \\
\end{array}$} & \multirow[t]{2}{*}{$\mathbf{t}$} & \multirow[t]{2}{*}{ Sig } & \multirow[t]{2}{*}{ Rank } \\
\hline & Variables & $\mathrm{B}$ & Std. Error & & & & \\
\hline \multirow{6}{*}{ 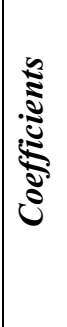 } & Constant & -.327 & .157 & & $2.089^{-}$ & .038 & \\
\hline & $\begin{array}{l}\text { Production and selling } \\
\text { place }(\mathrm{x} 1)\end{array}$ & .137 & .030 & .159 & 4.587 & .000 & $3^{\text {rd }}$ \\
\hline & Marketing factors(x2) & .465 & .060 & .409 & 7.743 & .000 & $1^{\mathrm{st}}$ \\
\hline & Promotion(x3) & .134 & .062 & .124 & 2.168 & .031 & 5 th \\
\hline & Distribution(x4) & .121 & .031 & .158 & 3.928 & .000 & $4^{\text {th }}$ \\
\hline & Pricing (x5) & .225 & .050 & .236 & 4.469 & .000 & $2^{\text {nd }}$ \\
\hline
\end{tabular}

$\mathrm{p}<0.05$

Source :( own survey, 2018)

Predictors: (Constant), Independent variables: Production \& selling place challenges, marketing factor challenge, promotion challenge, distribution challenge, pricing challenges, government support \& legal procedures 
challenge \& infrastructure challenge. The unstandardized coefficients B column, gives us the coefficients of the independent variables in the regression equation including all the predictor variables as indicated below.

\section{Unstandardized coefficient Interpretation:}

Keeping all other variables constant

- For every one unit increment on production and selling place the performance of SMEs increases by $13.7 \%$

- For every one unit increment on marketing factors the performance of SMEs increases by $46.5 \%$

- For every one unit increment on promotion the performance of SMEs increases by $13.5 \%$

- For every one unit increment on distribution channels the performance of SMEs increases by $12.5 \%$

- For every one unit increment on pricing the performance of SMEs increases by $22.5 \%$

Predicted performance score $=-.327+0.137$ (production \& selling place) +0.465 (marketing factor) +0.135 (promotion) +0.125 (distribution) +0.225 (pricing) Table 4.14 further showed that, all the explanatory variables included in this study can significantly explained at $95 \%$ confidence level $(p<0.05)$ to the variation on the dependent variable.

The standardized beta coefficient column indicated the contribution of individual variables that makes to the model. The beta weight is the average amount the dependent variable increases when the independent variable increased by one standard deviation (all other independent variables are held constant). As these are standardized we can compare them. Thus, the largest influence on the performance of SMEs is from the marketing factor challenges $(0.465)$ and the next is pricing $(0.225)$. On the other hand production $\&$ selling pace (0.137) next high a beta value, promotion (0.135), distribution challenge also have standardized beta value of 0.125 .

\section{Standardized coefficients Interpretations:}

* A 1 standard deviation increase in standardized production and selling place is predicted to result in 0.159standard deviation increases in standardized SMEs performance, other remaining variables holding constant

* A 1 standard deviation increase in standardized marketing factor is predicted to result in 0.409 standard deviation increases in standardized SMEs performance, other remaining variables holding constant

* A 1 standard deviation increase in standardized promotion is predicted to result in 0.124 standard deviation increases in standardized SMEs performance, other remaining variables holding constant.

* A 1 standard deviation increase in standardized distribution channels is predicted to result in 0.158standard deviation increases in standardized SMEs performance, other remaining variables holding constant

* A 1 standard deviation increase in standardized pricing is predicted to result in 0.236 standard deviation increases in standardized SMEs performance, other remaining variables holding constant

\subsection{Hypothesis testing and discussion}

\subsubsection{Hypothesis testing}

Hypothesis testing is the method of testing weather claims or hypothesis regarding a population are likely to be true. The goal of hypothesis is to determine the likelihood that a population parameter. Here there are two hypothesis: null (Ho), and alternative (Ha). The significance (sig) values expressed a value to accept or reject the (null) hypothesis. It is also called the p-value. The p-value is the probability that the correlation is one just by chance. Therefore, the smaller the $\mathrm{p}$-value, the better will be. The general rule is reject $\mathrm{Ho}$, if $\mathrm{p}<0.05$ and accept if $\mathrm{P}>0.05$ (pallant, 2016). In this part of the study, proof of the null hypothesis is made based on the above table 4.18 for the variables. Because, to test the research hypothesis already set in chapter one, it is possible to find out if the independent variables are significant predictors of the dependent variable. To test these relationships, the regression analysis was applied.

\section{Ho1: Production and selling place challenges has no significant effects on SMEs performance}

Production and selling place challenges doesn't have statically significant effects on SMEs performance. (Hol is rejected if $\mathrm{p}<0.05$ ), otherwise accept it. From table 4.18 the significant value for production \& selling place is 0.000 which is less than $\mathrm{p}$ value 0.05 . $(\mathrm{P}<0.05)$. Therefore Ho1 is rejected, which indicates that production and selling place has a significant effects on SMEs performance. Besides the value of beta for production and selling place $(\beta=0.159)$ this shows that production and selling place has significant effects on SMEs performance. This implied that a one standard deviation increases in production \& selling place increases in 0.159 standard deviation in SMEs performances. Hence, the above proposed null hypothesis is rejected and the alternative hypothesis is accepted; which indicates that production and selling place significantly and statistically effects on SMEs performance.

This study supported by the studies of (Hailay,2003) the main problems of Small \& medium business in 
Ethiopia are lack of appropriate selling place, production place, lack of quality raw materials, expensiveness of different machineries, and materials. According to the reports of (FeMSDA, 2015) Manufacturing and service SMEs faced on inadequate production and selling places. According to (EDRI, 2014) identified that constraints in the area of working and selling places including limited accessibility of sheds, distant location of constructed sheds, and gradual return ability of sheds without any replacement of another place.

Ho2: Marketing factors has no significant effect on SMEs performance.

Marketing factors doesn't have significant effects on SMEs performance (Ho2 rejected if $\mathrm{p}<0.05$ ), otherwise accept it. From table 4.18, the significant value for marketing factors is 0.000 , which is less than $p$ value 0.05 . Therefore, Ho2 is rejected, which indicates that marketing factors has significant effects on SMEs performance in Loka Abaya woreda. Besides the value of beta for market factors challenge $(\beta=0.409)$ this shows that marketing factors has significant effects on SMEs performance. Hence, the above proposed null hypothesis is rejected and the alternative hypothesis is accepted; which indicates that marketing factors significantly and statistically effects on SMEs performance. This implied that a one standard deviation increases in marketing factors increases in 0.409 standardized increases in standardized SMEs performances.

This study supported by the studies of (HLCEP, 2006), the major challenges of SMEs in developing countries are low ability to acquire entrepreneurial skills, and managerial expertise, lack of marketing skills and knowledge. Another study (EDRI, 2004) Major marketing challenges of SMEs in developing countries are problems of conducting market research and not working with marketing research organizations, poor implementation of packages coupled with limited market information.

Ho3: Promotion challenge has no significant effect on marketing performance.

A promotion challenge doesn't have significant effects on SMEs performance. (Rejected Ho3 if $p<0.05$ ) otherwise accepted. From table 4.18, the significant value for promotion 0.031 which is less than p value 0.05 .

Therefore Ho3 rejected which indicate that promotion challenges have significant effects on SMEs performance in study area. Besides, the above table depicted that the value of standardized beta value of promotion challenge $(\beta=0.124)$ this shows that the positive influence of promotion on SMEs performance. Thus, the above proposed hypothesis is rejected and alternative hypothesis is accepted. This implied that a one standard deviation increases in promotion increases in 0.124 standard deviation in SMEs performances. This study supported by different studies: According to the reports of (MoTI, 2011) major SMEs in Ethiopia faced lack of e-promotional activities, lack of effective advertisement, public relations, and exhibitions, effective trade fair and bazaars.

Ho4: A Distribution channels have no significant effect on marketing performance of SMEs.

Distribution channels don't have significant effects on SMEs performance. (Rejected Ho4 if $\mathrm{p}<0.05$ ) otherwise accepted. From table 4.18, the significant value for distribution channels 0.000 which is less than $\mathrm{p}$ value 0.05 . Therefore Ho4 rejected, which indicates that a distribution channel has significant effects on SMEs performance in Loka Abaya woreda. Besides the value of beta for distribution channels challenge $(\beta=0.158)$ this shows that distribution channels has significant effects on SMEs performance. Hence, the above proposed null hypothesis is rejected and the alternative hypothesis is accepted; which indicates that distribution channels challenge significantly and statistically effects on SMEs performance. This implied that a one standard deviation increases in distribution channels, increases in 0.158 standard deviation in SMEs performances. This studying supported by different studies according to (N.G. Nair \& Latha Nair, 2010) most of SMEs goods and services are needed effective distribution channels to reach end user of product and services, in marketing activities involved in the movement or the flow of goods or services from the primary producer to the ultimate consumer. According to (Gerehiwot, A, and Wolday, A., 2004) Ethiopians SMEs faced different challenges like lack of appropriate distribution channels, lack of whole sellers, distributors, and retailers.

\section{Ho5: Pricing challenges has no significant effect on SMEs performance.}

Pricing doesn't have significant effects on SMEs performance. (Rejected Ho5 if $\mathrm{p}<0.05$ ) otherwise accepted. From table 4.18, the significant value for pricing 0.000 which is less than p value 0.000 . Therefore Ho5 rejected, which indicates that pricing has significant effects on SMEs performance in Loka Abaya woreda.

Besides the value of beta for pricing challenge $(\beta=0.236)$ this shows that pricing has significant effects on SMEs performance. Hence, the above proposed null hypothesis is rejected and the alternative hypothesis is accepted; which indicates that pricing challenge significantly and statistically have effects on SMEs performance. This implied that a one unit standard deviation increases in standardized pricing increases 0.236 standard deviation in SMEs performances. This study supported by studies of (Mulugeta, 2011) Most of SMEs faced lack of pricing skill, how to set price of the product, lack of knowledge to administer their profit, accounting knowledge and poor follow up their business.

\section{CONCLUSIONS}

This research was conducted in Loka Abaya woreda Sidama zone, SNNPRS with the prime intent of critically assessing the effects of marketing challenges on the performance of SMEs operators (owners) engaged in manufacturing, trade, services, construction, and urban agriculture enterprises business activities. Specifically, 
the study attempted to examine the production \& selling place challenges, marketing challenges, promotion challenges, distribution channels, pricing challenges, government support and legal procedures and infrastructure challenges that affect the performance of SMEs. Based on the objectives and findings of the study, the following conclusions were drawn.

All independent variables value influenced SMEs performance ( $\mathrm{R}$ square value) is $80.5 \%$ remaining value $19.5 \%$ covered by other variables(influenced by other factors) Marketing factors challenge have highest standardized beta value 0.409 it indicates 1 standardized deviation increases in standardized marketing factors is predicted to result in 0.409 std. deviation increases in standardized SMEs performance.

Most SMEs in the Woreda faced inadequate production and selling place, working and selling place problems mostly affects the performance of SMEs. The rent for house and machinery was very high so that enterprises cannot pay expensive prices for the house \& machinery. In the study area, small $\&$ medium enterprises faced lack of market for their products; the farness (distance) of the well known market affects performance of SMEs. In addition operators of SMEs \& managers didn't have marketing knowledge and skills to produce and sell the products in competitive market. Lack of demand forecasting of the products and working with marketing research organizations mostly affects the marketing performance of SMEs in study area.

The major challenges of promotion factors was lack of internet access to deliver information about the product and shortage of network access, shortage of sales promotion, lack of exhibition and trade fair, publicity and advertisement ineffectiveness to promote the products of SMEs for customers or communicated with the customers affected the marketing performance of SMEs. These are major promotion challenges that affect performances of SMEs in Loka Abaya woreda.

Distribution channels challenges that affects the performance of SMEs were, shortage of suppliers of raw materials as input for SMEs, shortage of distributors, whole sellers, and retailers as well as lack of loyal (constant) customers is one of major distribution channels challenges that affected the performance of SMEs in study area.

On the other hand pricing challenges, lack of skill to set price of products of SMEs, high cost of raw materials affects the marketing performance of SMEs, SMEs product is not based on market price which means they set the price of product as they want, machinery cost was very expensive.

In general, marketing factors challenges have highest rank as compared to other challenges of SMEs in the study area. The next higher mean result is distribution channels challenges of SMEs.

\section{RECOMMENDATIONS}

The following recommendations are forwarded for corrective and complementary measures to enhance the potential marketing performances of SMEs.

SMEs operators and managers should work with marketing research organizations; they should use marketing knowledge, marketing skills, and know about how to forecast marketing demand in order to manage marketing activities of SMEs and customer handling.

SMEs should hire qualified skillful marketing person

Better the responsible bodies of Sidama zone, Loka Abaya Woreda officials should give training and experience sharing for managers and operators of SMEs in how to set the price of products and customer handling.

Government of Woreda and SMEs should create trade fair and exhibition, bazaars to show the products of SMEs in the Woreda. They are also required to create huge market in the Woreda in order to sell their products, operators of SMEs in Woreda and managers should create distributors, whole sellers, retailers, constant (loyal customers). Operators should evaluate, and facilitate Suppliers of raw materials.

They should evaluate the effectiveness of distribution channels to enhance sales of SMEs.

Loka Abaya woreda government \& stake holders' should provide suitable production and selling places for SMEs businesses and create conducive environments for SMEs development to contribute economic transformations of the country and employment creation.

In general the government responsible bodies, Sidama zone, Loka Abaya Woreda and SMEs themselves should solve marketing challenges: like production and selling place constraints, marketing factors challenges, promotional problems, distributional channel challenges, and, pricing problems to improve the performances of SMEs \& make them competent and profitable.

\subsection{DIRECTIONS FOR FUTURE RESEARCHER}

The current study investigated only marketing challenges that affect performances of SMEs in Loka Abaya Woreda. Future researchers may encompass more Woredas in Sidama zone, and also future researchers may focus on market linkages for SMEs products and customers' relations management practices of SMEs. 


\section{REFERENCES}

- Assegedech W. (2004). Marketing Strategies for Micro and Small Enterprises in Ethiopia: Ethiopian Business Development Services Network (EBDSN), Addis Ababa.

- Anderson, Dennis, and Carrier L. (1994). Small Industry in Developing Countries: Some Issues. World Bank Staff king Paper 518. Washington, D.C.

- Babbie, E. \& Mouton, J. (2002). The practice of social research. Cape Town: Oxford University Press.

- Berihu A, Abebaw, and Biruk T. (2014). Identifying Key Success Factors and Constraints in Ethiopia's MSE Development: An Exploratory Research. Ethiopian Development Research Institute (EDRI) Report 18, Addis Ababa, Ethiopia.

- Cheungsuvadee, K. (2006). Business adaptation strategies used by small and medium Retailers in an increasingly competitive environment: a study of UbonRatchathani, Thailand. http://ro.ecu.edu.au/theses/57

- Cohen, M. (2002). Making microfinance more client-led, Journal of International Development.

- Cooper, D. R. \& Schindler, P. S. (2003). Business Research Methods, 8th edition. New York: McGraw-Hill Irwin.

- Cooper, D. R. \& Schindler, P. S. (2008). Business Research Methods, 10th edition. Boston: McGraw-Hill Irwin.

- Copestake, J., Bhalotra, S., and Johnson, S. (2001). Assessing the impact of microcredit: A Zambian case study', Journal of Development Studies. 37(4).

- Department for International Development, (2000). Enterprise Development Strategy. New York; Rutledge.

- Dereje L. (2008). Micro and Small Scale Enterprises in the Construction Sector in Addis Ababa: The case of Gullele, Kirkos and Yeka sub-cities. MA thesis in Regional and Local Development Studies. RLDS, Addis Ababa University.

- Dichter, Thomas W, (1994). Compromise and cheating in small enterprise development. In:Malcolm Harper and Jim Tanburn (eds), 2005. Mapping the shift in business development services, Making Markets Work for the Poor. Warwickshire: ITDG Publishing.

- DOTE, (2014). BDS Market Assessment in Bahir Dar, Hawassa, Addis Ababa and Mekelle Cities, Addis Ababa, Ethiopia.

- DP Eric E. Ronge and Hezron O. Nyangito, (2002). A review of Kenya's current Industrialization policy, No. 3. ISBN $996694902 \mathrm{X}$

- Elias B. (2005). Role of Micro and Small Enterprises in Local Economic Development, The Case of Hawassa, in Tegegne G/E, and Helmsing A.H.J,(Eds), Local Economic Development in Africa, Enterprises Communities and Local Government. The Netherlands, Shaker Publishing.

- Eshetu B \& Mammo M. (2009). Promoting micro, small and medium Enterprises for sustainable rural Livelihood; DIIPER Working Paper No.11 Aalborg University Denmark

- Eshetu B, \& Zeleke W. (2008). Factors that Affect the Long-term Survival of Micro, Small, and Medium Enterprises in Ethiopia. South African Journal of Economis.10(2)

- Esther, K. Ishengoma., and Robert Kappel. (2008).Business Constraints and Growth Potential of Micro and Small Manufacturing Enterprises in Uganda.

- European Commission (1998). The Contribution of Business Services to Industrial Performance, a Common Policy Framework; Communication from the Commission to the Council, Brussels, 21.9.

- Federal Democratic Republic of Ethiopia (FDRE), Ministry of Finance and Economic Development (MoFED), (2010). Growth and Transformation Plan 2010/11-2014/15. Addis Ababa Ethiopia.

- Federal Democratic Republic of Ethiopia (FDRE), Ministry of Trade and Industry (MoTI), (1997). Micro and Small Enterprise Development Strategy. Addis Ababa, Ethiopia.

- Federal Democratic Republic of Ethiopia (FDRE), Central Statistical Authority. (2003). Report on BiAnnual Employment Unemployment Survey, 1st year Round 1, statistical Bulletin 319.

- Federal Democratic Republic of Ethiopia (FDRE), Central Statistical Authority. (2005:13-15). Report on Bi - annual Employment, unemployment survey. 1st round 2, Statistical Bulletin 301.

- Federal Micro and Small enterprises Development Agency Establishment council of Ministers (2011: 5766). Federal Negarit Gazeta of the federal democratic Republic of Ethiopia. Regulation No. 201/2011, Addis Ababa.

- Fisseha Y. (1992). 'Small Scale Enterprises in Lesotho: Summary of a Country-wide Survey'. Gemini Technical Report No.14, Washington D.C. Development Alternatives Inc.

- Gebrehiwot, A. and Wolday, A. (2004). MSEs Development in Ethiopia: Survey Report. A.A, Ethiopia.

- Gerber-Nel, C., Nel, D. \& Kotze, T. (2005). Marketing research. Claremont: New Africa Books (Pty) Ltd.

- Goldmark, L., and Nichter, S. (2005). Understanding Micro and Small enterprise Growth Accelerated Micro enterprise advancement project United Nation USAID.

- Haftu B, TseahyeT, Teklu K and Tassew W/H. (2009). Financial Needs of Micro and Small Enterprise (MSE) Operators in Ethiopia. Occasional Paper No. 24 Addis Ababa, Ethiopia 
- Hailay, G. (2003). Entrepreneurship and Small Business Management. Ethiopia Central Printing Press. Mekelle.

- Hair, F.J., Wolfinbarger, M. Ortinau, D.J. \& Bush R.P. (2008). Essentials of Marketing Research, New York: McGraw-Hill/Irwin.

- High Level Commission on Legal Empowerment of the Poor (HLCLEP). (2006). Background Issue Paper on Legal Empowerment of the Poor: Entrepreneurship. Draft Document. Addis Ababa, Ethiopia.

- Hope, K. R., Sr. (2001). Development policy and management in Africa. Gaborone: Center of Specialization in Public Administration and Management, University of Botswana.

- International Labor Organization (2008). Profile of Employment and Poverty in Africa. Report on Ethiopia, Nigeria, Ghana, Tanzania, Kenya, and Uganda. East Africa Multi-Disciplinary Advisory Team (EAMAT). Geneva, ILO Publications.

- Kayanula, D. \& Quartey, P. (2000). The Policy Environment for Promoting Small and Medium-sized Enterprises in Ghana and Malawi. Paper No.15. Institute of Development Policy and Management, University of Manchester.

- Karl-Oskar Olming. (2004). Commercially Sustainable BDS to poor Customers: The Case of Sir Lanka. ILO.

- Kebede, B. (2015). The Challenges of Micro and Small Enterprises and Business Development Service. Addis Ababa University: Addis Ababa Ethiopia.

- Liedholm, Carl and Donald C. Mead, (1999). Small Enterprises and Economic Development: The Dynamics of Micro and Small Enterprises. London and New York; Rutledge.

- Mead, D.C. and C. Liedholm (1998). 'The dynamics of micro and small enterprises in developing countries, World Development 26(1): 61-74.

- Mulu G. (2009). Innovation and Micro enterprises Growth in Ethiopia. Word Institute for Development, Economic research, United Nations University, No. 51.

- Mulugeta C.W,. (2010). Factors affecting the performance of Women Entrepreneurs in Micro and small enterprises (the case of Dessie Town). A Thesis Presented in Partial Fulfillment of the Requirements for Degree of Master of Arts in Technical and Vocational Education Management, Bahir Dar University, Ethiopia.

- $\quad$ N.G.Nair \& Latha Nair,(2011). "Sales and Distribution Management", $2^{\text {nd }}$ Edition, Himalaya Publishing House, New Delhi.

- Simeon Nichter and Lara Goldmark. (2009). Small Firm Growth in Developing Countries. World Development, 37(9).

- Swierczek, F. W. \& Ha, T. (2003). Entrepreneurial orientation, uncertainty avoidance and firm performance: an analysis of Thai and Vietnamese SMEs. International Journal of Entrepreneurship and Innovation, 4(1).

- Tegegne G, \& Meheret A. (2010). Micro and Small Enterprises as Vehicles for Poverty Reduction, Employment Creation and Business Development: The Ethiopian Experience. Forum for Social Studies, Research Report No.6 Addis Ababa, Ethiopia.

- $\quad$ Todaro, M.P. and S.C. Smith (2003). "Economic Development"; 8th edition; Pearson: Addison Wesley.

- United Nations Industrial Development Organization (UNIDO), (2002). Rural Enterprise Development Support Project. Entrepreneurial Skills for group based SMEs. Trainers Manual.

- World Bank. (2004). "Small and Micro Enterprises". World Bank Group Review of Small Business Activities. Washington, DC: World Bank

- Wolfeson, J. D. (2007). 'The Challenges of Globalization: the role of the World Bank. Paper presented at the address to the Bundestag Berlin, Germany.

- Zeleke W. (2009). Efficiency in Management as a Determinant of Long-term Survival in Micro, Small and Medium enterprises in Ethiopia. Problems and Perspectives in Management, 7(3). 